\author{
Arkadiusz Piotr Nowak \\ Poznań University of Economics and Business \\ Institute of Socio-Economics \\ Department of Sociology and Business Ethics \\ e-mail: Arkadiusz.Nowak@ue.poznan.pl
}

\title{
Problem możliwości etyki zawodowej pośredników kredytu hipotecznego
}

\section{The possibility of professional ethics for mortgage brokers}

The purpose of this work is to present arguments that support the thesis about the need to formulate professional ethics for mortgage brokers. Due to the lack of a broader reflection on the professional ethics of this profession, a theoretical gap has arisen between general ethical thinking and the practice of ethical codes. Based on the literature, it was found that to formulate professional ethics, it is necessary to know the specifics of the work and to identify the specific ethical problems of the profession. These issues for mortgage brokers are described in this paper thanks to the use of the retrospective participant observation method. The conclusions of this study make it possible to recommend formulating the basics of professional ethics that refer to the value of professionalism, honesty, and responsibility.

Keywords: mortgage brokers, professional ethics, business ethics

JEL Classification: A12, G21, M14

\section{Wprowadzenie}

Ponad połowa wszystkich kredytów hipotecznych w Polsce jest obecnie udzielana przy udziale pośredników kredytu hipotecznego. W 2018 roku przy ich pomocy klienci uzyskali kredyty na sumę ponad 27,5 mld złotych. Oznacza to, że pośred- 
nicy kredytu hipotecznego stali się istotnym partnerem zarówno dla instytucji finansowych, jak i konsumentów. Mając na względzie potrzebę podjęcia szczególnej refleksji etycznej w świecie finansów (Dembinski, 2017) oraz precyzyjnego określania oczekiwań społecznych wobec grup zawodowych (Klimczak, 1997), uzasadnione wydaje się przeanalizowanie specyfiki pracy pośredników kredytów hipotecznych w celu wskazania szczególnych obszarów ryzyka nadużyć. Ich rozpoznanie pozwoli na dalszą pogłębioną refleksję na temat kondycji etycznej branży pośrednictwa kredytowego, a także na podjęcie rozważań nad możliwością wyeliminowania występującej tam złej sprzedaży (Lazari-Pawłowska, 1969; Nowak-Gocławski, 2018). Aby móc umieścić tę problematykę w szerszym kontekście refleksji nad etyką różnych zawodów (Luban, 2007), konieczne jest rozpoznanie specyficznych problemów etycznych dla danej profesji (Klimczak, 2010). Punktem wyjścia przeprowadzonych badań nad wskazanym tu problemem było sformułowane w postaci hipotezy badawczej następujące przypuszczenie: w pracy pośrednika kredytu hipotecznego występują specyficzne problemy etyczne, które uzasadniałyby sformułowanie etyki zawodowej dla tej profesji.

Aby móc zweryfikować przedstawioną hipotezę, zbudowany został schemat pracy pośrednika kredytu hipotecznego. Powstał on dzięki wykorzystaniu metody retrospektywnej obserwacji uczestniczącej (Bulmer, 1982). Następnie dokonano oceny poszczególnych etapów pracy w ramach opisanego schematu w kontekście szerszej refleksji etycznej określonej na podstawie badań literaturowych.

\section{Miejsce pośrednictwa kredytu hipotecznego w przestrzeni prawnej, ekonomicznej oraz etycznej}

\subsection{Regulacje prawne zawodu pośrednika kredytu hipotecznego}

Jeszcze kilka lat temu osoby zajmujące się wspieraniem klientów w uzyskaniu kredytu hipotecznego nazywano ogólnie doradcami finansowymi. To niezbyt precyzyjne określenie dotyczyło szerokiego obszaru usług zarówno w zakresie kredytów, ubezpieczeń, inwestycji, jak i produktów biznesowych. W marcu 2017 roku uchwalono ustawę o kredycie hipotecznym oraz o nadzorze nad pośrednikami kredytu hipotecznego i agentami (Ustawa, 2017), będącą implementacją dyrektywy hipotecznej, co szczegółowo zostało już opisane przez Krzysztofa Waliszewskiego (2017). W ramach tych przepisów uregulowana została praca podmiotów, które mogą zajmować się pośrednictwem kredytu hipotecznego. Podmiotami tymi są: pośrednik kredytu hipotecznego, jego personel, agenci pośrednika i personel agenta (Rysunek 1). Dla ułatwienia, dla celów niniejszej pracy określenie pośrednik kredytu hipotecznego będzie się odnosiło do wszystkich podmiotów wykonujących czynności pośrednictwa kredytu hipotecznego na rzecz więcej niż jednego kredytodawcy, niezależnie od tego, czy jest to sam pośrednik, jego agent czy personel. 


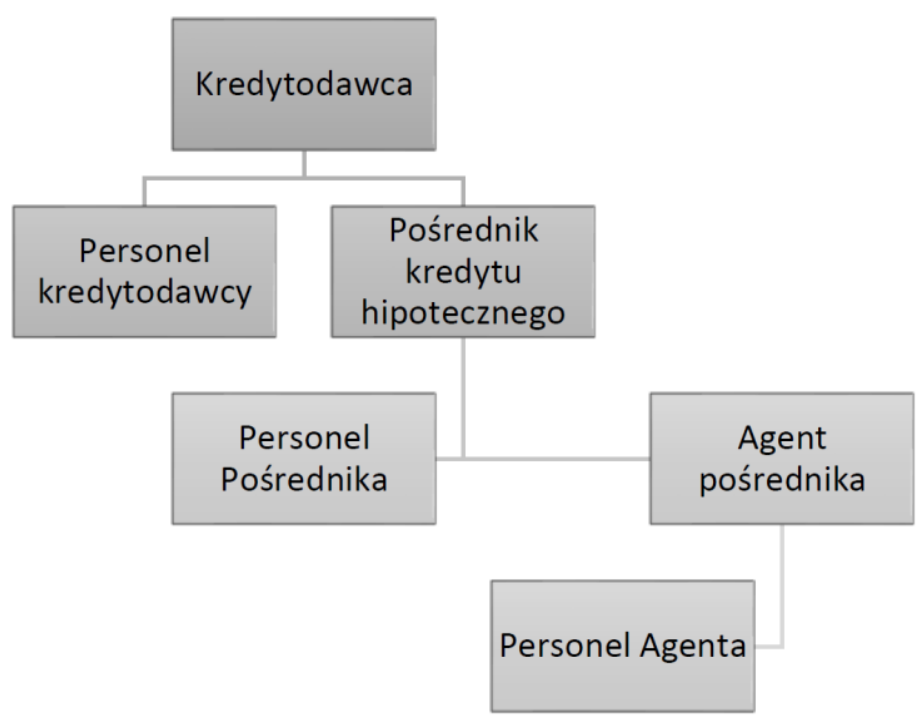

Rysunek 1. Podmioty związane z pośrednictwem kredytu hipotecznego

Źródło: opracowanie własne.

Podstawowym zadaniem pośrednika kredytu hipotecznego jest wspieranie klientów w procesie starania się o uzyskanie finansowania na cele związane z zaspokojeniem potrzeb mieszkaniowych. Szczególnie dotyczy to takich obszarów, jak pomoc w przeanalizowaniu ofert kredytowych, kompletowaniu dokumentów oraz kontakcie z bankami. Warto zaznaczyć, że w trakcie tego procesu pośrednik nie może wskazywać rekomendacji wyboru określonego kredytodawcy, gdyż jest to zarezerwowane dla usług doradczych. Wówczas na pośredniku ciążą zupełnie inne zobowiązania, dlatego specyfika tego rodzaju usług nie jest uwzględniona $\mathrm{w}$ niniejszej pracy.

Ponadto wspomniana ustawa nakłada na pośredników szereg obowiązków, takich jak: uzyskanie odpowiedniego wpisu do rejestru prowadzonego przez Komisję Nadzoru Finansowego, posiadanie ważnej polisy OC, spełnianie licznych obowiązków informacyjnych wobec klientów. Dodatkowo ustawodawca zobowiązał pośredników do przyjęcia i stosowania zasad dobrych praktyk.

\subsection{Ekonomiczne znaczenie branży pośrednictwa kredytu hipotecznego}

W dziale I rejestru pośredników kredytowych prowadzonego przez Komisję Nadzoru Finansowego na dzień 13.03.2020 r. wpisanych było 756 pośredników kredytu hipotecznego (Rejestr pośredników..., 2020). Jednocześnie zaledwie jedna czwarta z nich świadczy usługi na rzecz więcej niż jednego kredytodawcy, a jedynie 10 pośredników może przedstawić ofertę więcej niż 10 kredytodawców. Mimo to udział pośredników w całkowitej sprzedaży kredytów hipotecznych wyraźnie 
wzrósł na przestrzeni lat, wynosząc w 2018 roku ponad 50\% zarówno pod względem liczby zawartych umów, jak i wartości sprzedaży liczonej według kwot kredytu (Wykres 1).

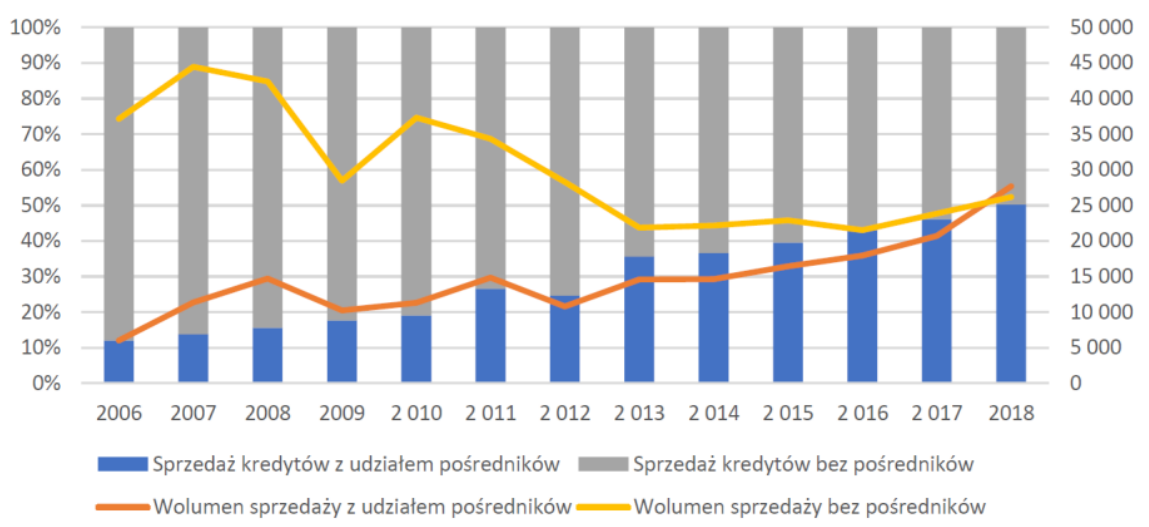

Wykres 1. Udział pośredników w całkowitej sprzedaży kredytów hipotecznych. Udział procentowy według liczby umów oraz wartość sprzedaży w mln zł.

Źródło: opracowanie własne na podstawie GUS oraz ZBP.

Z powyższego wynika, że branża pośrednictwa kredytu hipotecznego stanowi coraz istotniejszą część rynku kredytowego. Wiąże się z tym jednak ogromna odpowiedzialność. Warto zauważyć, że pośrednictwo kredytu hipotecznego mieści się na styku trzech ważnych makroekonomicznie rynków: rynku konsumentów, rynku nieruchomości i rynku kapitałowego. Dlatego tym bardziej istotne jest, by pośrednicy kredytowi funkcjonowali sprawnie, efektywnie i z poszanowaniem wartości etycznych zawodu. Ma to znaczenie nie tylko ze względu na potrzeby budowania zaufania do branży finansowej (Dembinski, 2012), ale również dla utrzymania własnej efektywności, która jest możliwa przy zachowaniu równoważnej relacji wobec interesariuszy (Freeman \& Evan, 1997).

\subsection{Miejsce refleksji nad etyką pośredników kredytu hipotecznego w kontekście ogólnej refleksji etycznej}

Etyka, będąca ogólnym namysłem nad moralnością, obejmuje w ramach etyk szczegółowych również bardzo konkretne obszary życia człowieka (Borkowski, 2009). Z kolei w ramach etyk szczegółowych można wyróżnić etyki zawodowe, w których dokonuje się odniesienia ogólnych zasad moralnych do konkretnych problemów i zagadnień danego zawodu (Klimczak, 2010). Pewnym przejawem etyki zawodowej są kodeksy etyczne (Lazari-Pawłowska, 1969), jednak nie są one wystarczające dla ukształtowania etyki zawodowej, gdyż nie dają wystarczająco silnych podstaw, do których można będzie odnosić coraz to nowe wyzwania etyczne (Kalokairinou, 2016). 
Należy zaznaczyć, że do branży pośrednictwa kredytu hipotecznego możemy odnieść również zagadnienia z pokrewnych etyk szczegółowych ze świata ekonomii, finansów czy biznesu. Dla przykładu warto wspomnieć choćby pogląd George'a DeMartino (2009), który, odnosząc się do ekonomistów, wskazuje, że przedstawiane przez nich opisy zjawisk dotyczą wymiaru społecznego zdarzeń, więc zawierają istotny poziom niepewności osądu, mimo że nie jest ona wprost wyrażana. Jednocześnie autor wskazuje na pewien intelektualny monopol, gdyż nawet podstawowe zagadnienia ekonomii są niezrozumiałe bez specjalistycznej wiedzy. Ekonomiści wpływają na życie ludzi przez różne rekomendacje polityczne lub dotyczące przedsiębiorczości, np. w zakresie oceniania efektywności, która ze względu na konsekwencje nie może być uznana za pozbawioną etycznego wymiaru koncepcję (Aldred, 2009). W tym zakresie konieczne jest uwzględnienie problemu niepewności co do wyrażanych sądów oraz poziomu wiedzy odbiorców jako przejaw odpowiedzialności. W tym kontekście podobną zależność można stwierdzić u pośredników kredytu hipotecznego, którzy również odnoszą się do niepewności (np. odnośnie do stóp procentowych, zmiany wartości zabezpieczenia). W podobny sposób do etyki ekonomistów odnosi się Wojciech Gasparski (2013), wskazując jednocześnie, że ich praca nie jest wyłącznie działaniem technicznym, ale obciążonym aksjologicznie, a wymiar etyczny jest warunkiem autentycznej odpowiedzialności za działania i ich skutki (Gasparski et al., 2011). W przypadku etyki zawodowej wydaje się jednak, że łatwiej jest uzyskać swoisty teoretyczno-praktyczny charakter podejmowanych rozważań (Grzybek, 2016), gdyż w swojej istocie polegają one na ocenie zgodności między oczekiwaniami a konkretnymi zachowaniami uczestników danej branży lub po prostu służą skorygowaniu stanu faktycznego (Lazari-Pawłowska, 1969). Na poziomie teoretycznym podstawową trudnością jest rozstrzygnięcie charakteru relacji między moralnością ogólną a moralnością wykonywanego zawodu (Galewicz, 2010; Luban, 2007). Czy są one zgodne czy sprzeczne, uzupełniające czy wykluczające? Przywołani autorzy zdają się zgodnie twierdzić, że występuje tu pewna, konieczna wręcz sprzeczność, gdyż niektórym osobom przyznajemy szczególne prawa i obowiązki właśnie ze względu na pełnione przez nie role. Dla przykładu możemy wskazać, że od adwokata nie wymagamy potępienia nagannych zachowań jego klienta, uważając, iż właściwe jest, by każdy miał prawo do obrony i procesu uwzględniającego różne racje. Dlatego w kontekście budowania różnych etyk zawodowych konieczne jest dobre poznanie specyfiki danej branży, by odpowiednio określić specyficzne obowiązki.

\subsection{Potrzeba opracowania etyki zawodowej pośredników kredytu hipotecznego}

Wielu autorów podkreśla szczególne miejsce etyki zawodowej jako etyki szczegółowej, znajdującej się w obrębie refleksji nad etyką gospodarczą. Mieczysław Gogacz (1998, s. 11) definiuje etykę zawodową jako teorię „odpowiedzialnej, a więc moralnie dobrze realizowanej pracy". Według Eleni Kalokairinou (2016) etyka zawodowa dostarcza ram teoretycznych, które pozwalają radzić sobie 
z napotkanymi problemami. George DeMartino (2009) pisze o uważności i świadomości etycznej, które zauważamy w wykonywanej pracy dzięki naukowej tradycji, dyskusji i krytycznym dociekaniom. Wyłania się więc obraz teoretyczno-praktycznego namysłu nad wykonywaną pracą (Gałkowski, 2002; Grzybek, 2016). Z kolei Bożena Klimczak (2010) podkreśla, że etyka zawodowa znajduje zastosowanie wyłącznie w tych profesjach, w których występują szczególne problemy etyczne. Jako że niniejszy tekst ma na celu przedstawienie argumentacji na rzecz sformułowania etyki zawodowej pośredników kredytu hipotecznego, uwzględniając opisany powyżej charakter rozważań, konieczne wydaje się w pierwszej kolejności potwierdzenie występowania specyficznych problemów etycznych tego zawodu, co podjęte zostanie w dalszej części pracy.

Należy zauważyć, że firmy pośrednictwa kredytu hipotecznego samodzielnie lub przez zrzeszenia, do których należą, zaimplementowały odpowiednie kodeksy dobrych praktyk, a te odwołują się do zasad moralnych. Odwołanie się do wartości jest niezwykle istotne dla trwałego ustanawiania wszelkich norm, jednak dobór wartości, które stanowić będą podstawę dla wyprowadzanych norm, jest kluczowy i wymaga dobrego rozeznania. Odwołanie się do określonych wartości jest jednak niewystarczające, bo dobór tychże wartości musi jak najbardziej precyzyjnie odpowiadać specyfice pracy w danym zawodzie i tworzyć spójny system. Grzegorz Grzybek (2016, s. 56) jako „kontrowersyjne” określa nastawienie na „ujęcie kodeksowe pozbawione odpowiedniej teorii wartości”. Dlatego też konieczne jest podjęcie refleksji nad specyfiką pracy pośredników kredytu hipotecznego, by określić wartości, które będą kluczowe dla sformułowania właściwych norm etycznych tego zawodu. Dzięki temu możemy uzyskać standard, który jest najbardziej trafny, ale też w sposób trwały będzie wpływał na kształtowanie moralności pracowników tego sektora.

Innymi słowy, należy uzupełnić refleksję etyczną oraz praktykę kodeksową o zagadnienia etyki zawodowej pośredników kredytu hipotecznego. W dalszej części pracy opisane zostanie badanie, dzięki któremu możliwe jest przeanalizowanie specyfiki pracy w tym zawodzie i określenie, z jakimi szczególnymi problemami etycznymi wiąże się ta praca. Wnioski z badania pozwolą natomiast na stworzenie podstaw etyki zawodowej dla pracowników tego sektora.

\section{Etapy pracy pośrednika kredytu hipotecznego}

\subsection{Metoda}

W celu realizacji założenia o konieczności dobrego poznania specyfiki danego zawodu dla potrzeb ustanowienia etyki zawodowej powstał schemat pracy pośrednika kredytu hipotecznego, opracowany dzięki zastosowaniu retrospektywnej obserwacji uczestniczącej (Bulmer, 1982). Metoda ta polega na odtworzeniu realiów zaobserwowanych $\mathrm{w}$ czasie bezpośredniego zaangażowania $\mathrm{w}$ wykonywane czynności przed przyjęciem perspektywy badacza. Autor niniejszego tekstu przez 
ponad 8 lat współpracował z różnymi firmami pośrednictwa kredytu hipotecznego, będąc częścią większych zespołów, ale również osobiście obsługując klientów i przeprowadzając łącznie około 200 procesów kredytowych. Spostrzeżenia dotyczą więc zarówno zaobserwowanych działań współpracowników, jak i tych wykonywanych osobiście $\mathrm{w}$ ramach określonych przez firmę standardów. Podjęta na tej podstawie refleksja pozwoliła na wyodrębnienie istotnych etapów wnioskowania o kredyt hipoteczny. Na każdym z nich zaobserwowano różne, specyficzne możliwości wpływu pośrednika na podejmowane przez klienta decyzje. Dlatego zasadne wydaje się wyszczególnienie tych obszarów wpływu, gdyż to w ich ramach może pojawiać się szczególne pole do nadużyć.

Dzięki powyższemu badaniu wyodrębnione zostały następujące etapy pracy pośrednika kredytu hipotecznego:

1. analiza potrzeb i możliwości;

2. przygotowanie dokumentacji do wniosku;

3. procesowanie wniosku przez kredytodawcę;

4. finalizacja.

W dalszej części pracy poszczególne etapy zostaną przedstawione, omówione oraz wskazane będą potencjalne obszary, w których może dochodzić do nadużyć.

\subsection{Analiza potrzeb i możliwości}

Na tym etapie procesu głównym zamierzeniem jest oszacowanie zdolności klienta do uzyskania kredytu oraz przygotowanie do złożenia wniosków kredytowych. Potrzebne jest do tego dobre rozeznanie w potrzebach oraz możliwościach finansowych i płatniczych klienta. Oferty bankowe bardzo różnią się między sobą pod względem cenowym oraz proceduralnym, co sprawia, że właściwy dobór propozycji finansowania dla klienta wymaga dobrej analizy i znajomości specyfiki poszczególnych kredytodawców. Innymi słowy, podczas wywiadu dokonuje się przede wszystkim negatywnej selekcji ofert banków, które są odrzucane ze względów proceduralnych, a mogą dotyczyć zarówno dochodów klienta (np. brak akceptacji formy zatrudnienia lub rodzaju dochodu), sytuacji materialno-finansowej (np. brak odpowiednio wysokiego wkładu własnego), jak i względów pragmatycznych (czas procesowania wniosku przekracza ustalone terminy płatności). Złożoność tych czynników sprawia, że ostateczny wybór kredytodawcy jest wyraźnie zindywidualizowany. Na tym etapie pojawia się kilka możliwości zaistnienia konfliktu. Dotyczy to sytuacji, w której pośrednik sugeruje ofertę tego banku, w którym łatwiej jest spełnić wymogi proceduralne, podkreślając jednocześnie uciążliwość innych procesów. Interes partykularny pośrednika przemawia za takim rozwiązaniem z kilku względów: po pierwsze szybszy proces to szybsze wynagrodzenie; po drugie unika on podejmowania dodatkowego wysiłku z powodu braku wystarczającej wiedzy i umiejętności, by sprawnie przeprowadzić proces w innym banku. W żargonie branżowym używa się nawet określenia ,proces szufladowy", który polega na tym, że pośrednik (czasem zachowuje się tak również oddział banku, dla którego wniosek nie daje perspektyw na sukces) przyjmuje wniosek, który leży w szufladzie i faktycznie nie jest procesowany. 
Przewagi proceduralne mogą również stanowić pretekst do wyboru kredytodawcy, który jest atrakcyjniejszy dla pośrednika ze względu na wysokość otrzymywanego wynagrodzenia. Nie jest tajemnicą, że istnieją różnice między bankami co do wysokości wypłacanego pośrednikom wynagrodzenia za kredyt. Zawsze jest ono uzależnione od kwoty kredytu, a czasem również od dodatkowych, sprzedawanych w pakiecie produktów (tzw. cross-sell), np. ubezpieczenia. Sugerowanie, by skorzystać z oferty banku dającego wyższe wynagrodzenie jest pokusą, która może się ujawnić już na tym etapie, choć zbyt wyraźna sugestia może być ryzykowna w momencie, gdy klient dopiero poznaje możliwości.

W kontekście wynagrodzeń warto wyjaśnić, że klient nie ponosi dodatkowych kosztów za korzystanie z usług pośrednika kredytu hipotecznego, gdyż bank nie różnicuje oferty dla klienta ze względu na źródło pozyskania. Oznacza to, że klient otrzymuje tę samą ofertę u pośrednika, co w oddziale banku. Uzasadnieniem tego stanu rzeczy jest fakt, że pracownicy oddziałów banku nie są angażowani na najbardziej czasochłonnych etapach obsługi klienta, co zostanie wykazane w dalszej części pracy.

\subsection{Przygotowanie dokumentacji do wniosku}

Po dokonaniu wyboru ofert (najczęściej dwóch lub trzech) następuje przygotowanie dokumentacji niezbędnej do złożenia wniosku w banku. Część druków przygotowuje samodzielnie pośrednik (np. uzupełnia wnioski, załączniki z danymi osobowymi, generuje księgę wieczystą, potwierdza dokumenty sprzedającego, udostępnia klientowi druki uznawane przez banki), a część klient (np. przekazuje zaświadczenie od pracodawcy o zatrudnieniu i zarobkach, sporządza wyciągi bankowe, generuje wyniki finansowe firmy). Konieczna jest wtedy ścisła współpraca pośrednika i klienta. Jest to etap wymagający największego zaangażowania po obu stronach, by zebrana dokumentacja była kompletna i odpowiadała procedurom określonym przez banki. Intensywność prac wynika również z presji czasu, która pojawia się $\mathrm{w}$ momencie podjęcia decyzji i podpisania umowy przedwstępnej zakupu nieruchomości. Presja ta wynika zarówno z terminów określonych w umowie, jak i terminów ważności sporządzanych dokumentów - wówczas może się okazać, że wydłużony czas oczekiwania na jeden z dokumentów powoduje konieczność aktualizacji drugiego, co generuje lawinowe opóźnienia w procesowaniu wniosku.

Jednym z kluczowych elementów problemowych, który dotyczy całego procesu, ale ujawnia się właśnie na etapie sporządzania dokumentacji, jest obowiązek zachowania tajemnicy, mający wieloaspektowy charakter. W podstawowym ujęciu pośrednik jest zobowiązany do nieujawniania osobom trzecim żadnych informacji na temat klientów. Pośrednik nie może nawet przekazać informacji, czy ktoś jest jego klientem czy nie. Problem ten może szczególnie ujawnić się w kontakcie ze sprzedającymi, którzy również chcieliby znać realny termin podpisania umowy przyrzeczonej. Czasem mamy do czynienia z sytuacją, gdy klient trafia do pośrednika z polecenia kogoś, kto wcześniej był przez niego obsługiwany. Wówczas pojawia się pokusa ujawnienia szczegółów tamtej transakcji, gdy np. nowy klient 
nie może uzyskać takiej samej oferty (ze względu na inną kwotę wnoszonego wkładu własnego, rodzaj transakcji itp.).

Po drugiej stronie obowiązku zachowania tajemnicy pojawia się problem jawności. Pokusa nieujawniania pewnych informacji pojawia się, gdy wiemy, że informacje te wpływają negatywnie na ocenę przez bank zdolności kredytowej klienta. Może to dotyczyć np. zobowiązań w instytucjach pozabankowych (które nie zawsze są widoczne w rejestrach), poręczeń kredytowych czy nawet liczby dzieci w gospodarstwie domowym. Przez ukrycie tych informacji bank zostaje wprowadzony w błąd i nie może prawidłowo oszacować ryzyka udzielenia kredytu. Stawia to przed nami pytanie o relację pośrednika wobec klienta oraz wobec banku. Traktując ich jako równorzędnych interesariuszy, konieczna wydaje się dbałość o interesy obu stron. Tym samym obowiązkiem pośrednika staje się co prawda reprezentowanie klienta, ale jednocześnie szukanie takich rozwiązań, by bank przy pełnej jawności mógł podjąć rzetelną decyzję w zakresie ryzyka udzielenia kredytu hipotecznego. Dużo trudniejsze w rozstrzygnięciu są sytuacje, gdy klient umawia się z pracodawcą, że na potrzeby starań o kredyt będzie uzyskiwał wyższy dochód. Trzy miesiące wyższego dochodu często wystarczą, by zgodnie z procedurą uzyskać kredyt, niezależnie od tego, że później dochód klienta jest realnie niższy.

Problem jawności może pojawić się również w innych, bardziej niespodziewanych sytuacjach, np. gdy klient zataja zobowiązanie wobec współmałżonka i nie ujawnia go na wspólnym spotkaniu, ale prosi o dopisanie dodatkowego kredytu później.

\subsection{Procesowanie wniosku przez kredytodawcę}

Na tym etapie komplet dokumentów trafia do banku, który na ich podstawie podejmuje decyzję kredytową. Procedura w tym zakresie jest wieloetapowa i najczęściej przebiega według schematu: decyzja wstępna $\rightarrow$ wycena nieruchomości $\rightarrow$ decyzja ostateczna $\rightarrow$ podpisanie umowy kredytowej. Na każdym etapie bank może prosić o dodatkowe wyjaśnienia i dokumenty. Co istotne, ze względu na złożoność procedur oraz wielkość zespołów analityków banki w różnych terminach realizują te procesy. Oznacza to, że po otrzymaniu decyzji kredytowej z jednego banku nadal trzeba czekać, jaką decyzję wyda drugi bank. Pojawia się tu podobne ryzyko, jak na etapie przygotowań, czyli pokusa realizacji procesu prostszego proceduralnie $-\mathrm{z}$ tych samych powodów, co wcześniej. Kwestie procedur i niepewności wynikającej z dłuższego terminu oczekiwania można również wykorzystać, by zachęcić klienta do skorzystania z oferty banku, który oferuje pośrednikowi wyższe wynagrodzenie. Jest to jeden $\mathrm{z}$ najtrudniejszych $\mathrm{w}$ ocenie momentów, gdyż między zachętą do skorzystania z określonej oferty a zwykłą informacją o ryzyku związanym $\mathrm{z}$ dalszym oczekiwaniem na decyzję $\mathrm{w}$ innym banku jest bardzo cienka granica. Zwłaszcza że ryzyko dłuższego oczekiwania na kolejną decyzję jest realne ze względu na niepewność wyniku analizy czy terminy ważności dokumentów. Warto też zaznaczyć, że uzyskanie finansowania na zakup własnego mieszkania to dla wielu osób niezwykle istotne wydarzenie, więc wy- 
dłużone oczekiwanie i związana z nim niepewność mogą powodować długotrwały stres. W takiej sytuacji większa jest skłonność do „kompromisu”, byle tylko odsunąć nieprzyjemne i niepewne oczekiwanie.

Pewne nadużycia mogą się również pojawić w obszarze sprzedaży produktów dodatkowych. Warto od razu zastrzec, że nie wszystkie produkty oferowane razem z kredytem hipotecznym należy odrzucić. Na przykład propozycja otwarcia konta osobistego, na które ma wpływać wynagrodzenie, wydaje się rozsądna, ale już ubezpieczenie od utraty pracy dla emeryta zdecydowanie nie. Warto więc rozróżnić, kiedy możemy mówić o złej sprzedaży (misselingu). Można przyjąć, że mamy z nią do czynienia w sytuacji, gdy klient otrzymuje produkt, „którego nie potrzebuje, nie rozumie, nie stać go na to lub za niegodziwą cenę" (Nowak-Gocławski, 2018, s. 14). Pokusa podjęcia takich działań może się pojawiać w dwóch sytuacjach: gdy bank dodatkowo płaci pośrednikowi za sprzedaż tego typu produktu lub pod presją pracownika banku, który potrzebuje tego do zrealizowania planów sprzedażowych. W skrajnych przypadkach klient otrzymuje informację, że zakup dodatkowego produktu jest wymagany do uzyskania pozytywnej decyzji kredytowej. Warto zauważyć, że na etapie bliskim finalizacji procesu kredytowego, po intensywnej pracy i konieczności przyswojenia przez klienta wielu nowych informacji, może się pojawić uczucie zmęczenia kwestiami finansowymi i tym samym obniżona czujność wobec propozycji zakupu produktów dodatkowych.

W ramach tego etapu prac istnieje jeszcze jedno ryzyko, które może wynikać $\mathrm{z}$ dobrej woli, ale złego porozumienia z klientem. Ma to miejsce, gdy na etapie wyboru dwóch lub trzech banków nie zostanie wskazany ten najbardziej przez klienta preferowany (lub preferencje się zmienią). Wówczas pośrednik może większą wagę przywiązywać np. do banku oferującego najniższy koszt całkowity kredytu, podczas gdy klient akceptuje wyższy koszt na rzecz innych korzyści. Praktyka pokazuje, że klienci często uwzględniają również pozafinansowe czynniki, takie jak: konieczność przeniesienia konta i trudności z tym związane, wysokość opłat początkowych, dostępność placówek czy zaufanie do instytucji.

\subsection{Finalizacja}

Niektóre elementy związane $\mathrm{z}$ finalizacją transakcji mogą pojawić się w środku procesu - zwłaszcza, jeśli wybrane banki prowadzą proces $\mathrm{z}$ etapem decyzji wstępnej, która do kontynuacji wymaga poniesienia kosztu związanego z wyceną nieruchomości. Decyzja o ostatecznym wyborze oferty może więc następować wcześniej. Niezależnie od tego przed podpisaniem umowy kredytowej klient musi nie tylko zapoznać się z jej treścią, ale również z warunkami, które należy spełnić przed podpisaniem umowy, przed uruchomieniem kredytu oraz $\mathrm{w}$ trakcie trwania kredytu.

Na tym etapie może dojść do bagatelizowania zagrożeń i ryzyka, związanych z długoterminowym zobowiązaniem finansowym (zmienność oprocentowania, postępowanie w przypadku braku spłaty itp.). Wydaje się, że mówienie o ryzykach wiąże się z przekazywaniem negatywnych informacji, a przecież chcieliby- 
śmy, żeby atmosfera spotkań była spokojna i przyjazna. Ponadto zagrożenia mogą wpłynąć na decyzję klienta o rezygnacji z takiego finansowania, co na tym etapie procesu, po dużym wkładzie pracy, mogłoby być nieprzyjemne (pośrednik otrzymuje wynagrodzenie wyłącznie za wypłacony kredyt). Co prawda informacje o ryzykach powinny pojawić się już na etapie przygotowań, ale omówienie umowy kredytowej wymaga ponownej analizy tych aspektów.

\section{Wnioski z badania - fundament etyki zawodowej pośredników kredytu hipotecznego}

Warto zauważyć, że dzięki powyższej analizie udaje się wskazać nie tylko obszar ryzyka powstawania nadużyć, ale również mechanizm działania w kierunku złej sprzedaży (np. wykorzystanie podatności na sugestie w czasie dużej niepewności i stresu). W Tabeli 1 przedstawiono w sposób uproszczony opisany wcześniej schemat działania. Wskazano w niej możliwe obszary nadużyć oraz przyczyny ich występowania.

Tabela 1. Obszary nadużyć oraz przyczyny ich występowania na poszczególnych etapach procesu kredytowego

\begin{tabular}{|c|c|c|}
\hline ETAP PROCESU & MOŻLIWE OBSZARY NADUŻYĆ & PRZYCZYNY NADUŻYĆ \\
\hline $\begin{array}{l}\text { Analiza potrzeb } \\
\text { i możliwości }\end{array}$ & $\begin{array}{l}\text { Potęgowanie trudności } \\
\text { proceduralnych; } \\
\text { Zła selekcja negatywna; }\end{array}$ & $\begin{array}{l}\text { Brak wiedzy i umiejętności; } \\
\text { Chęć uzyskania wynagrodzenia } \\
\text { szybciej lub więcej; }\end{array}$ \\
\hline $\begin{array}{l}\text { Przygotowanie } \\
\text { dokumentacji do wniosku }\end{array}$ & $\begin{array}{l}\text { Zła jakość składanych } \\
\text { dokumentów; } \\
\text { Ujawnianie istotnych informacji } \\
\text { a zachowanie tajemnicy; }\end{array}$ & $\begin{array}{l}\text { Brak wiedzy i umiejętności; } \\
\text { Brak poczucia odpowiedzialności } \\
\text { za powierzone dane i za relację } \\
\text { z interesariuszem; }\end{array}$ \\
\hline $\begin{array}{l}\text { Procesowanie wniosku } \\
\text { przez kredytodawcę }\end{array}$ & $\begin{array}{l}\text { Nakłanianie do ostatecznej } \\
\text { decyzji - wykorzystanie } \\
\text { niepewności i stresu; } \\
\text { Sprzedaż dodatkowych } \\
\text { produktów; }\end{array}$ & $\begin{array}{l}\text { Przyspieszenie uzyskania } \\
\text { wynagrodzenia; } \\
\text { Zwiększenie wysokości } \\
\text { wynagrodzenia; }\end{array}$ \\
\hline Finalizacja & $\begin{array}{l}\text { Bagatelizowanie zagrożeń } \\
\text { i ryzyka; }\end{array}$ & Brak poczucia odpowiedzialności. \\
\hline
\end{tabular}

Źródło: opracowanie własne.

Łatwo zauważyć, że opisane przyczyny sprowadzają się do trzech głównych kategorii:

1. brak wiedzy i umiejętności;

2. dążenie do uzyskania wynagrodzenia (w ogóle lub wyższego);

3. niedostatek odpowiedzialności.

Oczywiste wydaje się zatem, by na podstawie tych kategorii określić wartości, które stanowiłyby fundament etyki zawodowej pośredników kredytu hipo- 
tecznego. Najbardziej odpowiednie do tych kategorii problemów byłyby takie wartości, jak: profesjonalizm, uczciwość i odpowiedzialność.

Profesjonalizm w tym przypadku przejawia się w dążeniu do podnoszenia kompetencji, dzięki czemu pośrednik będzie potrafił bardziej trafnie dopasowywać oferty do potrzeb klientów, a także skutecznie przekazać wiedzę na temat specyfiki kredytu hipotecznego i ryzyk z nim związanych. Przewaga pośrednika nad klientem w obszarze posiadania wyspecjalizowanej wiedzy, czyli nierównowaga nazywana przez George'a DeMartino (2013) epistemiczną asymetrią, zdaje się warunkiem koniecznym dla zachowania profesjonalnego charakteru działań, dlatego nieustanne dążenie do podnoszenia wiedzy i umiejętności jest niezbędnym elementem dbałości o zachowanie profesjonalizmu zawodu. To z kolei pozwoli na utrzymanie właściwego poziomu zaufania do branży, chroniąc przed erozją norm i ideałów wykonywanego zawodu (Luban, 2007).

Przyjęcie uczciwości jako jednej z wartości ma uświadamiać rolę wynagrodzenia za wykonaną pracę. Właściwe wykonanie usługi przez pośrednika daje przecież korzyści obu stronom. Klient otrzymuje stosowną pomoc, a pośrednik wynagrodzenie. Zachowanie zasady uczciwości przez pośrednika i transparentne podejście do kwestii własnego wynagrodzenia przynosi korzyść w postaci dobrej reputacji, która z kolei przekłada się na większą liczbę klientów. Złamanie tej zasady przez wykorzystanie przez pośrednika przewagi wiedzy lub tym bardziej chwili słabości klienta z powodu stresu i niepewności, oprócz tego, że zasługuje na szczególne napiętnowanie, wpływa negatywnie na reputację jego oraz całej branży pośrednictwa kredytu hipotecznego. Uczciwość należy więc traktować nie tylko jako indywidualną deklarację, ale również jako zobowiązanie wobec branży kredytowej oraz społeczności pośredników kredytu hipotecznego.

Mając na względzie fakt, że klienci podejmują wysokie kwotowo i długotrwałe zobowiązania, zasada odpowiedzialności za przedstawiane oferty powinna być szczególnie istotna. Doświadczenie badacza wskazuje, że klienci są bardziej skłonni zrezygnować z transakcji ze względu na brak wiedzy o zagrożeniach, niż ze względu na faktyczne ryzyka. Poczucie odpowiedzialności pośrednika należy w sobie wypracować, gdyż w istocie transakcja odbywa się między kredytodawcą a kredytobiorcą, a wpływ pośrednika, mimo że istotny, pozostaje niejako niewidoczny. Zwłaszcza że klienci, dokonując wyborów, podejmują decyzje, opierając się również na pozafinansowych czynnikach (Cox et al., 2016). Zrozumienie zasady odpowiedzialności to $\mathrm{w}$ dużej mierze kwestia szacunku dla potrzeb i oczekiwań klientów.

Wydaje się, że opisane specyficzne problemy etyczne w pracy pośredników kredytu hipotecznego wzmacniają argumentację na rzecz tezy o konieczności sformułowania etyki zawodowej dla tej profesji. Przedstawione badanie wskazało możliwe obszary nadużyć, a także potencjalne ich przyczyny, dlatego niniejsza praca może stanowić podstawę do sformułowania takiej etyki, bazującej na profesjonalizmie, uczciwości i odpowiedzialności. Konieczne jest natomiast dalsze rozpoznanie tematu, by móc w sposób skuteczny i trwały zaproponować spójny system etyczny, który będzie chronił klienta oraz wzmocni dobre praktyki pośredników. 


\section{Bibliografia}

Aldred, J. (2009). The skeptical economist: Revealing the ethics inside economics. London: Routledge. https://doi.org/10.4324/9781849773263

Borkowski, T. (2009). Filozoficzne i pragmatyczne ograniczenia etyki biznesu. Annales. Etyka w Życiu Gospodarczym, 12(1), 109-118. http://www.annales online.uni.lodz.pl/archiwum/2009/2009_01_borkowski_109_118.pdf

Bulmer, M. (1982). When is disguise justified? Alternatives to covert participant observation. Qualitative Sociology, 5(4), 251-264. https://doi.org/10.1007/ BF00986753

Cox, J., List, J., Price, M., Sadiraj, V., \& Samek, A. (2016). Moral Costs and Rational Choice: Theory and Experimental Evidence. National Bureau of Economic Research. Working Paper 22234. https://doi.org/10.3386/w22234

DeMartino, G. (2009). On the Need for Professional Economic Ethics. Challenge, 52(4), 6-15. https://doi.org/10.2753/0577-5132520401

DeMartino, G. (2013). Epistemic Aspects of Economic Practice and the Need for Professional Economic Ethics. Review of Social Economy, 71(2), 166-186. https://doi.org/10.1080/00346764.2013.799967

Dembinski, P. H. (2012). Finanse po zawale: od euforii finansowej do gospodarczego ładu. Warszawa: Wydawnictwo Studio Emka.

Dembinski, P. H. (2017). Etyka i odpowiedzialność w świecie finansów. Warszawa: Wydawnictwo Studio Emka.

Freeman, R. E., \& Evan, W. M. (1997). Spółka i osoby żywotnie zainteresowane: Kapitalizm kantowski. W: L. V. Ryan \& J. Sójka (red.), Etyka biznesu: Z klasyki wspótczesnej myśli amerykańskiej (s. 185-205). Poznań: Wydawnictwo „W drodze”.

Galewicz, W. (2010). W sprawie odrębności etyk zawodowych. W: W. Galewicz (red.), Moralność i profesjonalizm: spór o pozycje etyk zawodowych (s. 9-119). Kraków: Towarzystwo Autorów i Wydawców Prac Naukowych UNIVERSITAS.

Gałkowski, J. W. (2002). Zasady etyki zawodowej - etyka biznesu. W: M. Borkowska \& J. W. Gałkowski (red.), Etyka w biznesie (s. 13-42). Lublin: Towarzystwo Naukowe KUL.

Gasparski, W. (2013). Czy ekonomiści powinni mieć kodeks etyczny? Postulaty, watpliwości, argumenty. IX Kongres Ekonomistów Polskich. Warszawa: Polskie Towarzystwo Ekonomiczne.

Gasparski, W., Lewicka-Strzałecka, A., Kuraszko, I., Bąk, D., \& Rok, B. (2011). Wolność czy swawola? Master of Business Administration, 19(5), 129-153.

Gogacz, M. (1998). Czym jest etyka zawodowa. W: A. Andrzejuk (red.), Zagadnienie etyki zawodowej (s. 11-14). Warszawa: Oficyna Wydawnicza „Navo”. 
Grzybek, G. (2016). Etyka zawodowa jako subdyscyplina naukowa (odniesienie do działalności zawodowej w obszarze nauczania, wychowania $i$ opieki). Rzeszów: Wydawnictwo Uniwersytetu Rzeszowskiego.

Kalokairinou, E. (2016). Professional Ethics. W: Encyclopedia of Global Bioethics (s. 2300-2311). https://doi.org/10.1007/978-3-319-09483-0_351

Klimczak, B. (1997). Etyczne otoczenie rynku kapitałowego. Wrocław: Wydawnictwo Akademii Ekonomicznej im. Oskara Langego.

Klimczak, B. (2010). Etyka zawodowa - jak to działa? Ekonomia i Prawo, 6, 15-24. https://doi.org/10.12775/EiP.2010.001

Komisja Nadzoru Finansowego (2020). Rejestr pośredników kredytowych-Dział I. https://www.knf.gov.pl/podmioty/posrednictwo_kredytowe/dzial_I

Lazari-Pawłowska, I. (1969). Etyka zawodowa. Etyka, 4, 58-80.

Luban, D. (2007). Professional Ethics. W: R. G. Frey, Ch. H. Wellman (eds.), A Companion to Applied Ethics (s. 583-596). Hoboken: Blackwell Publishing. https://doi.org/10.1002/9780470996621.ch43

Nowak-Gocławski, A. (2018). Dlaczego tolerujemy misselling w branży finansowej? W: K. Waliszewski (red.), Społeczna odpowiedzialność instytucji finansowych. Od teorii do praktyki (s. 13-22). Warszawa: CeDeWu.

Ustawa z dnia 23 marca 2017 r. o kredycie hipotecznym oraz o nadzorze nad pośrednikami kredytu hipotecznego i agentami. (2017). Dz.U. 2017 poz. 819.

Waliszewski, K. (2017). Zmiany w pośrednictwie kredytowym w Polsce w wyniku implementacji dyrektywy hipotecznej. Rozprawy Ubezpieczeniowe, 2(24), 3-17. 